\title{
Attitudes and beliefs about minimum wage in Kosovo - results of a public survey
}

\author{
Herolinda Murati-Leka**and Doruntina Ajvazi ${ }^{b}$ \\ aSouth East European University \\ bUniversity of Prishtina
}

A B S T R A C T

The minimum wage has long been regarded as a vital tool for ensuring labour market stability, and its impact and implications on employment, poverty reduction, the informal sector, and economic development, in general, have sparked a multi-year discussion. Based on a poll of 635 respondents, we present an analysis of the minimum wage in Kosovo's economy in this study. Our poll results reveal that our respondents had good attitudes toward the minimum wage and its increase in the Kosovo economy, as measured by the standard of living, employment, private sector, poverty reduction, and other factors. Kosovo has the lowest minimum wage in Central and Eastern Europe - 130 euros for those under 35 and 170 euros for those over 35 .

\section{ARTICLE INFO}

Keywords: Minimum wage, Kosovo, labour market, economic development. *Corresponding author: Herolinda
Murati-Leka
muratiherolinda@gmail.com

\section{Article history:}

Received: 09.02.2021

Revised: 14.03.2021

Accepted: 01.06.2021

DOI

https://doi.org/10.51410/jcgirm.8.1.10

\section{Introduction}

The minimum wage has long been a subject of research for numerous authors, who have sparked debates over its effects on the Labour market and other sectors. The minimum wage has been an essential part of public policy for more than a century. According to the OECD (2015), the legal minimum wage is the government's most direct policy lever for influencing wage levels, particularly workers in a weak negotiating position. According to Neumark and Wascher (2008), the minimum wage began in New Zealand and Australia in the 1890s and expanded to the United Kingdom in 1909 and then to the United States in the next two decades.

Webb (1912), Stigler (1946), Welch (1974), Brecher (1974), Gramlich (1976), Grossman (1983), Katz and Krueger (1992), Card and Krueger (1993; 1995), Cahuc and Michel (1996), Neumark and Wascher (1992; 1994; 1995), Lee (1999), and many others have written about the minimum wage and its effects. Furthermore, economists are attracted by the minimum wage because they have solid theoretical predictions regarding the direction of the minimum wage's effect on employment and pretty wellaccepted methodologies for estimating the magnitude of that impact (Brown, 1988). 
Minimum wages have followed an uneven trend in the past, owing to political and economic factors (Horrigan and Mincy, 1993). According to Rutkowski (2003), the minimum wage is a source of significant theoretical and political debate. Furthermore, if a government uses the minimum wage extensively to achieve various economic policy goals, it will, willingly or not, diminish the role of collective wage bargaining to regulate better its development (Eyraud and Saget, 2005).

This article is organized into five sections and analyses the minimum wage and its impacts in Kosovo. Based on several writers, the first section provides a theoretical review of the minimum wage in general and its implications on the Labour market, poverty, other earnings, and informality. The impact of the minimum wage on Kosovo is the subject of the second section. The third section continues with the study data collection instrument and data analysis and the survey outcomes that we did with our respondents. Finally, we present our observations and recommendations in the final section.

\section{Literature Review}

According to Marinakis (2009), when the International Labour Organization was established in 1919, the minimum wage was applied to a very small number of countries within a limited range. Trade committees for specific industries ("sweat industries") have tried to prevent exploitation in the UK, especially of women and domestic workers. Australia and New Zealand have established minimum wages by industry and region. Six states in the United States and four provinces in Canada have passed minimum wages laws. The textile industry has experience setting minimum wages in France and Norway, especially for domestic workers. (Marinakis, 2009).

Consistent with Suryahadi et al. (2003), as a result of changes in Labour market policy in the late eighties, minimum wages became a vital plank of Labour policy, as is clear from the speed at which the government has hyperbolized its levels. Nevertheless, despite many decades of micro econometric proof, the minimum wage remains a significantly disputed policy (Harasztosi and Lindner 2019). The minimum wage policy will have varied objectives, adopt specific mechanisms and procedures, use different criteria for setting it or ending ulterior changes, and have additional or less broad coverage (Infante et al. 2003). As expressed by Herr and Kazandziska (2011), there are several institutional queries regarding a wage policy that is associated with several country-specific factors, like the development stage of a rustic, the national characteristics of the labour market, the sort of commercial relations and union power, and the economic conditions, as well as several alternative factors.

Belman and Wolfson (2014) argue that employment, specifically the number of jobs, is a state of affairs for disputes regarding wages and their effects. Furthermore, as Del Carpio and Pabon (2017) claim, a large body of literature identifies combination effects such as reductions in formal employment and range of hours worked, hyperbolic states, and additional informal Labour, especially when the wage is exceptionally high.

Policymakers have perpetually seen the wage as a tool to form stability within the Labour market. In addition, Neumark and Wascher (1992), Brown et al. (1982), Aaronson and French (2007) and Meer and West (2015) stated that the minimum wage hurts employment.

On the other hand, Horrigan and Mincy (1993) believe that raising the minimum wage reduces the income gap between workers in two main ways. First, this increase reduces the income gap between older workers and younger workers, and second, this increase reduces the income gap 
between high-status and low-status occupational workers (Horrigan and Mincy, 1993). Furthermore, according to Stigler (1946), if the minimum wage is adequate, it must have one of two effects: first, workers whose service value is less than the minimum wage are fired, or second, raise lower wages and efficient worker productivity (Stigler, 1946). As Freeman (1996) asserted, an adequate minimum wage will, at best, make the income distribution beneficial to low-income people and support the bottom of the distribution.

Evidence from traditional econometric research generally shows that when the minimum wage is binding, an increase in the minimum wage increases wages in the formal sector (on a large scale) (Gindling and Terrell, 2005). Furthermore, Grossman (1983) pointed out that, in general, given the relative wages of the skill set, the company's demand for Labour is modelled on the choice of the skill set that minimizes cost. Therefore, the relationship between the minimum wage and wage distribution can be used to infer the low-wage labour market (Cengiz et al., 2019).

The widespread popularity of raising the minimum wage is primarily based on its attractiveness as an anti-poverty policy. It is based on two beliefs: the first is that raising the minimum wage will increase low-income families' income, and the second is that the minimum wage has little effect. In addition, Dolado et al. (1996), OECD (2015), and Clemens and Wither (2019) concluded that the minimum wage improves the standard of living of low-income workers.

However, as mentioned above, the impact of the minimum wage varies from country to country. Therefore, Zavodny (2000) pointed out that implementing a binding minimum wage will reduce the total Labour demand and increase the Labour supply. As the economy develops, Labour relations have shifted from rural to urban areas and have occurred in larger and larger companies. Employers and employees have begun to pay taxes, and workers have received legal protection, which generally includes minimum wage guarantees (Dinkelman and Ranchhod 2012).

Harrison and Leamer (1997) stated that after introducing a minimum wage that increases wages in the formal sector, some workers become unemployed. This will increase the supply of Labour in the informal Labour market, thereby reducing wages in the informal sector (Harrison and Leamer, 1997). Furthermore, if the minimum wage encourages workers to migrate from the formal to the informal sectors, then an increase in Labour supply in the informal sector can, in theory, lower informal wages (Fajnzylber, 2001).

\section{An overview of Minimum Wage in Kosovo}

For many years, the minimum wage has been seen as a tool for improving the labour market's quality and as well as a challenging issue. However, as we stated above, the effect of the minimum wage can sometimes have a negative effect on the Labour market, reducing poverty and the informal sector.

Kosovo faces significant economic challenges as a new country, including the Labour market. Unemployment remains the main problem in Kosovo, especially for young people, and the minimum wage has not increased since 2011. Based on the Labour Force Survey 2019 by the Kosovo Agency of Statistics, the rate of participation in the Labour force in 2019 was 40.5\%, the employment rate was 30.1\%, and the unemployment rate was 25.7\% (KAS, 2020a). 
Table 1. Key indicators of the labour market in Kosovo (\%), 2019

\begin{tabular}{|l|l|l|l}
\hline Key indicators of the labour market (\%) & Male & Female & Total \\
\hline Rate of participation in Labour force & 59,7 & 21,1 & 40,5 \\
Inactivity rate & 40,3 & 78,9 & 59,5 \\
Employment to population ratio (employment rate) & 46,2 & 13,9 & 30,1 \\
Unemployment rate & 22,6 & 34,4 & 25,7 \\
Unemployment rate among young people (15-24 years of age) & 44,1 & 60,3 & 49,4 \\
\hline
\end{tabular}

Source: (Authors' Compilation adapted from KAS, 2020a)

Based on the data of Kosovo Agency of Statistics, in 2012, the average gross salary in Kosovo was 383 Euros, while in 2019 it was 477 Euros, an increase of 94 Euros or $24.5 \%$, while the net salary from 348 Euros in 2012, increased to 430 Euros in 2019, an increase of 82 Euros, or 23.5\% (KAS, 2020b).

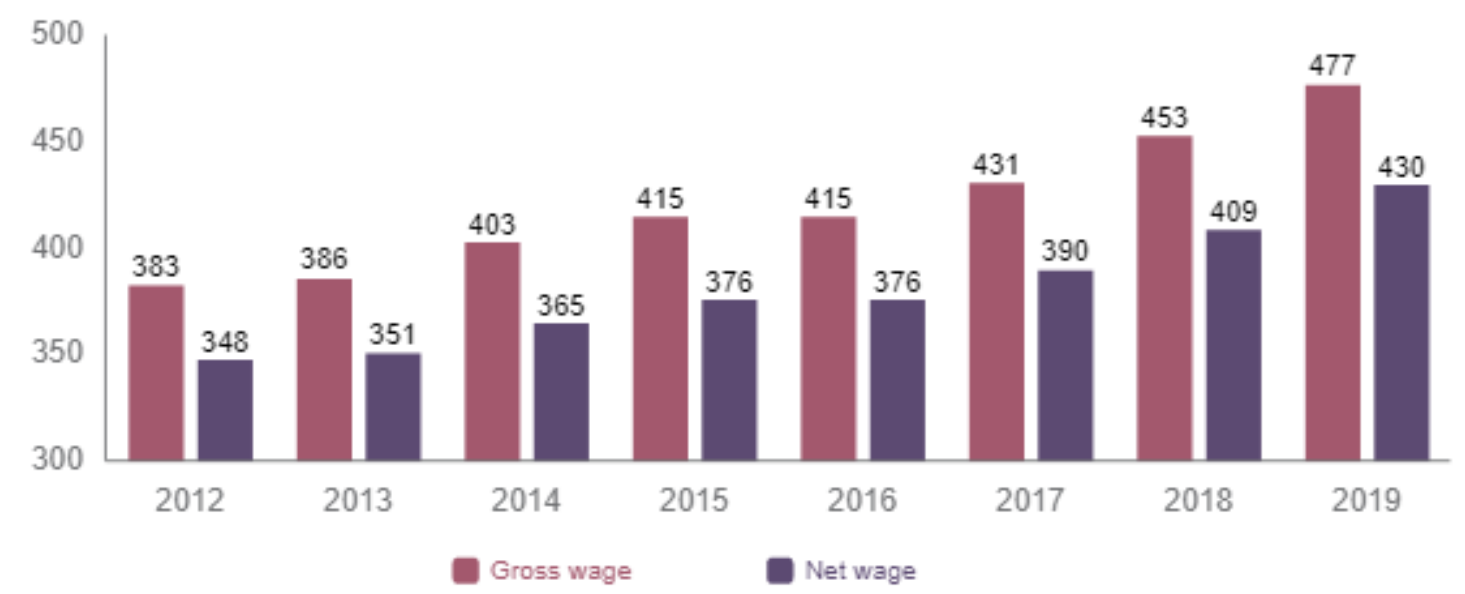

Figure 1. Average gross and net wage (in Euro), 2012 - 2019

Source: (Authors' Compilation adapted from KAS, 2020)

According to the Eurostat database 2020 and KAS, Kosovo has the lowest minimum wage in Central and Eastern European countries. The graph below shows that the highest minimum wage in the second half of 2020 was recorded in Slovenia (940.58 euros) and the lowest in Kosovo (170 euros), which has not changed since 2011. 


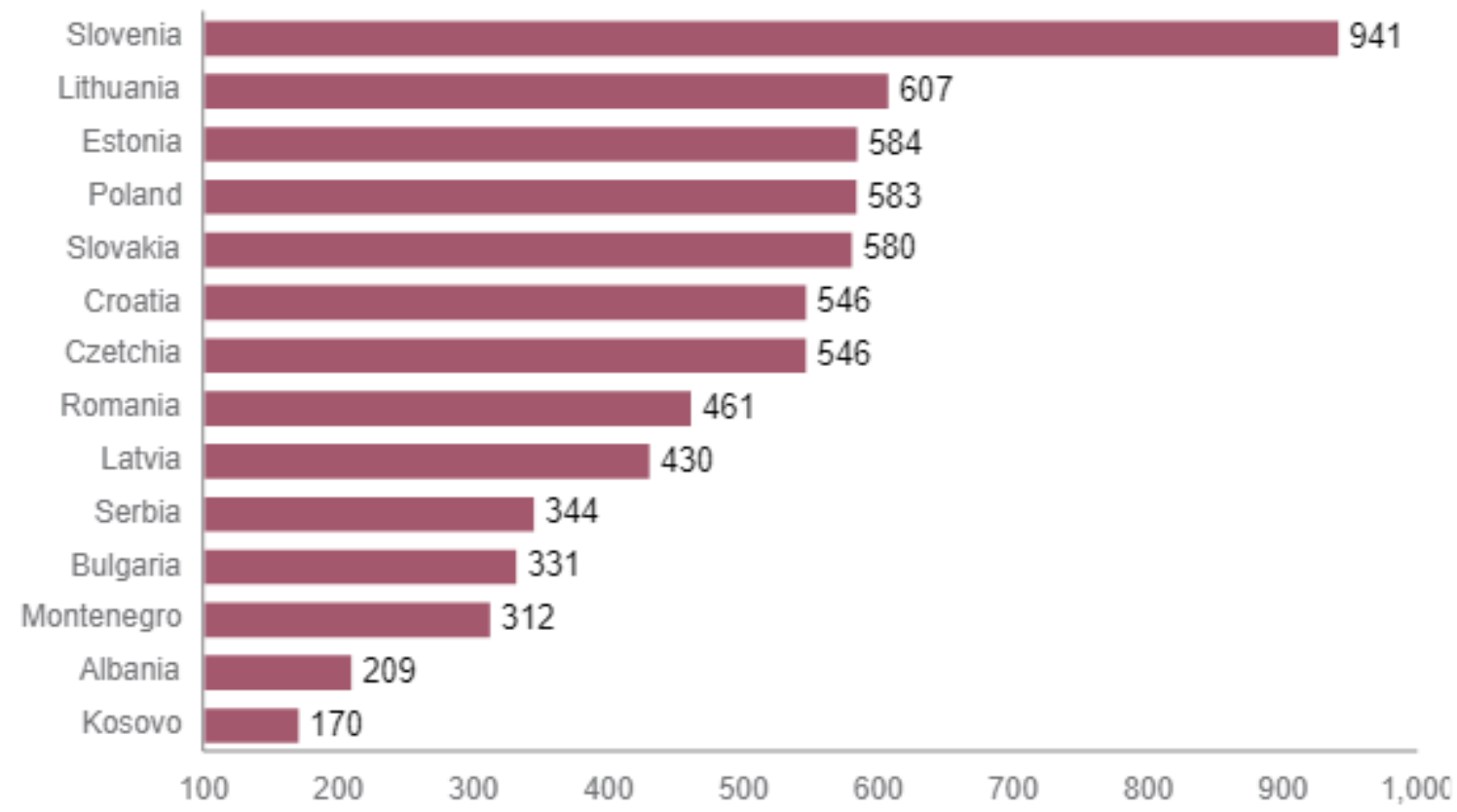

Figure 2. Minimum Wage in Central and Eastern European countries in 2020 S2 (in euros)

Source: Eurostat database 2020 for other countries. (Authors' Compilation adapted from KAS, 2020b) for Kosovo

Based on Article 57 of the Labour Law, the Government of Kosovo at the end of each calendar year sets the minimum wage on the proposal of the Economic and Social Council based on the following factors: the cost of living expenses; unemployment rate; the general situation in the labour market; and the degree of competition and productivity in the country (Official Newspaper of the Republic of Kosovo, 2010). According to the Kosovo Agency of Statistics data, in Kosovo, currently, the minimum wage is 130 euros for employees under the age of 35 and 170 euros for employees over the age of 35 , and it has not changed since 2011.

Table 2. The ratio of the minimum wage to average gross and net wage (in Euro) in Kosovo, 2019

\begin{tabular}{l|l|l|l}
\hline Age Group & Minimum wage & Gross (\%) & Net (\%) \\
\hline Until the age of 35 & 130 & 27,25 & 30,23 \\
Over 35 years old & 170 & 35,64 & 39,53 \\
\hline
\end{tabular}

Source: (Authors' Compilation adapted from KAS, 2020b).

\section{Instrument for Collecting Research Data and Analyzing Research Data}

In this research, we have used primary quantitative data, which has been collected from primary sources chosen randomly. The survey is considered the most relevant data collection instrument for this study. The survey was designed after researching scientific works conducted by other authors on minimum wage. Consequently, we composed a survey with 21 questions. An item consistency test was performed to ensure that the survey questions stood alone as a set. A reliability test has been conducted to verify the quality of the measurement procedure chosen for this study.

While passing these two steps successfully, pilot testing began. After that, the final version of the survey is designed and distributed to the respondents. The time frame for gathering data 
from the survey was from the $23^{\text {rd }}$ of March to the $19^{\text {th }}$ of April 2021. The platform Google Forms is used to collect responses. The responses have good representation among different disciplines, job positions, age, education, and wage rate.

The self-administrated survey has been distributed online randomly, and 635 respondents have filled it out. The respondents have been asked to give answers ranging from general ones about their age, level of education, and employment status to more concrete ones, like their opinion about the impact of the minimum wage on other economic phenomena.

The data collected from the survey has been analyzed using SPSS, Statistical Package for Social Science, and the graphs have been designed from the Excel Spreadsheet Database of the survey, generated from Google Forms.

Our survey has been representative, including people of different profiles such as managers, finance officers, administrators, teachers, sales agents, accountants, doctors, and project coordinators.

The survey results show that $40 \%$ of the respondents are between 25 and 34 years old, and $37 \%$ of them are between 15 and 24 years old. Regarding gender, $50 \%$ of respondents are female, and $50 \%$ are male. Furthermore, more than half of the respondents have completed their university education (57\%), and 59\% of the respondents are employed.

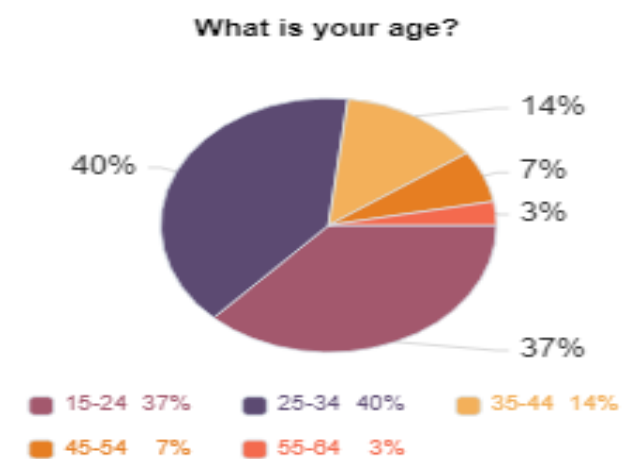

(a)

What is the highest level of education you have completed?

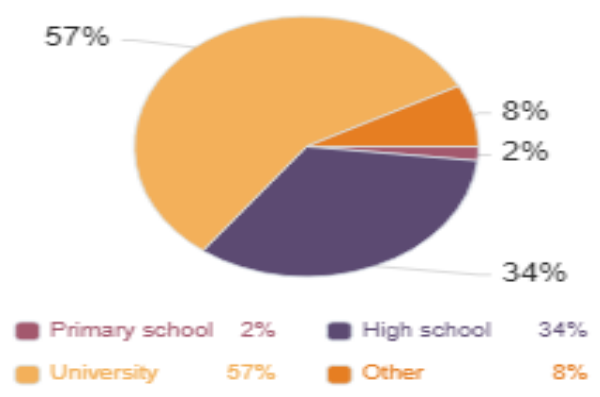

(c)

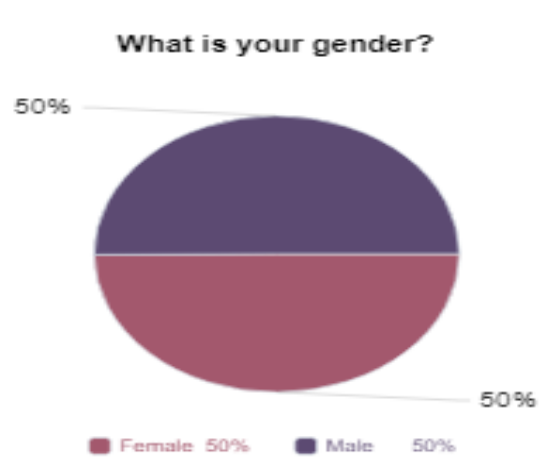

(b)

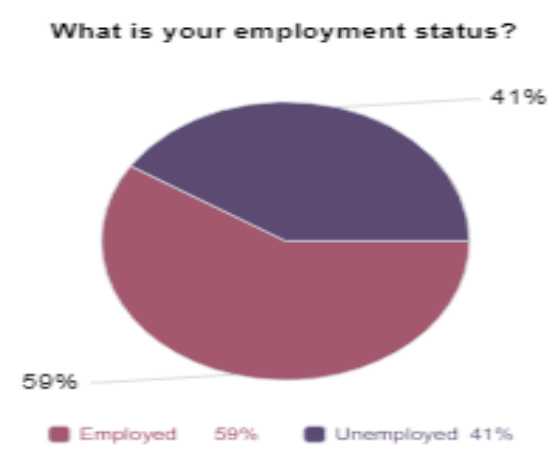

(d)

Figure 3. Results about the age, gender, education, and the employment status of the respondents.

Source: Data obtained from the author's survey conducted for this paper named "Attitudes and beliefs about minimum wage and its effect in Kosovo's economy - results of a public survey." 
In the fifth question, respondents were asked their opinion about the minimum wage as a reason why they have difficulty finding a job or are unemployed. 52\% of respondents think that there are other factors as well. On the other hand, $40 \%$ of respondents think that the minimum wage is why they have difficulty finding a job or are unemployed.

\section{In your opinion, do you think that the minimum wage is the reason why you have difficulty finding a job or you are unemployed?}

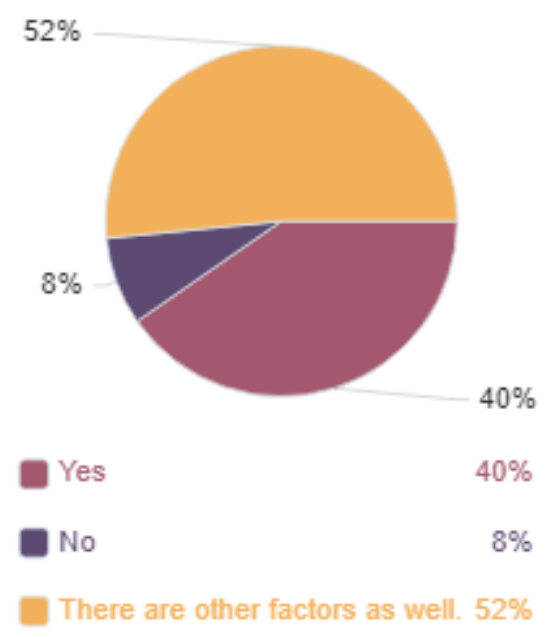

Figure 4. Respondents' attitudes about the effect of minimum wage finding a job or being unemployed.

Source: Data obtained from the author's survey conducted for this paper named "Attitudes and beliefs about minimum wage and its effect in Kosovo's economy - results of a public survey."

Most of the respondents (81\%) work in the private sector and $36 \%$ of them are paid between $251-450$ EUR.

If the previous answer was 'employed',
indicate in which sector do you work

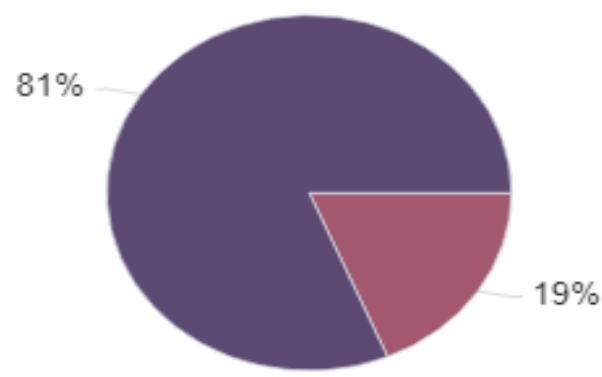

Public sector $19 \%$

Private sector $81 \%$

(a)
Indicate what is your salary

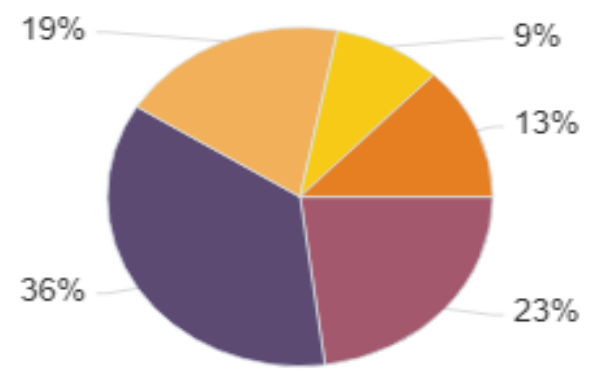

170-250 EUR $23 \%$

451-650 EUR $19 \%$

$251-450$ EuR $36 \%$

651-850 EUR 9\%

Over 850 EUR $13 \%$

(b)

Figure 5. Respondents answers about the sector they work in and their salary.

Source: Data obtained from the author's survey conducted for this paper named "Attitudes and beliefs about minimum wage and its effect in Kosovo's economy - results of a public survey." 
In the question in which respondents were asked for the impact of minimum wage in their work/ career, more than half $(70 \%)$ of respondents think that minimum wage has/has had an impact on their work/career.

From your experience, do you think that the minimum wage has/has had an impact on your work/career?

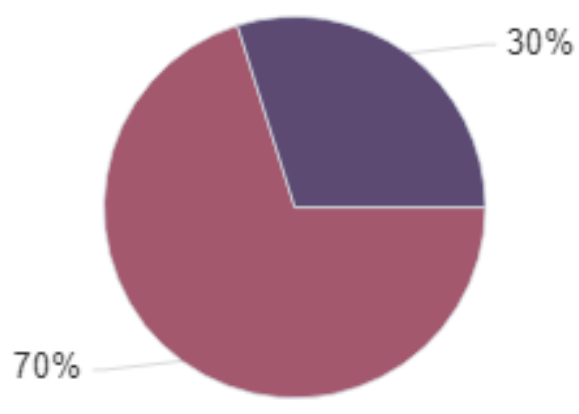

Yes $70 \%$ No $30 \%$

Figure 6. Respondent's answers about the impact of minimum wage on their work/career.

Source: Data obtained from the author's survey conducted for this paper named "Attitudes and beliefs about minimum wage and its effect in Kosovo's economy - results of a public survey."

Based on our survey results, $68 \%$ of respondents strongly agree that the minimum wage in Kosovo should be increased.

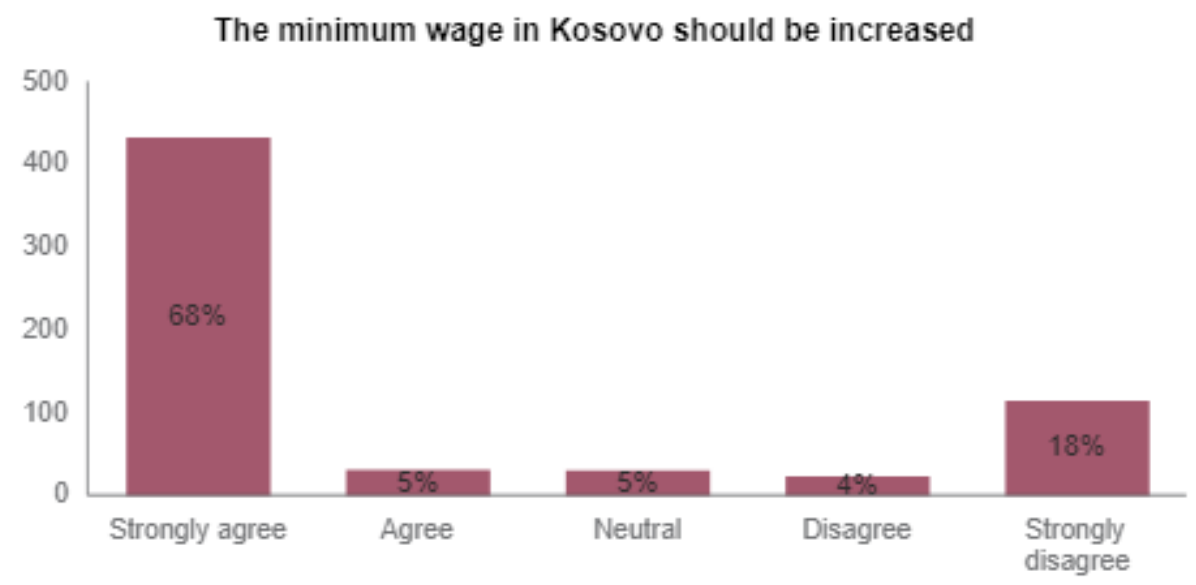

Figure 7. Respondent's answers about increasing minimum wage.

Source: Data obtained from the author's survey conducted for this paper named "Attitudes and beliefs about minimum wage and its effect in Kosovo's economy - results of a public survey."

Most of the respondents, $75 \%$, strongly disagree, and $18 \%$ agree that the minimum wage in Kosovo is enough to support a family. On the other hand, $18 \%$ strongly disagree that the minimum wage is enough to support a family. 
The minimum wage in Kosovo is enough to support a family

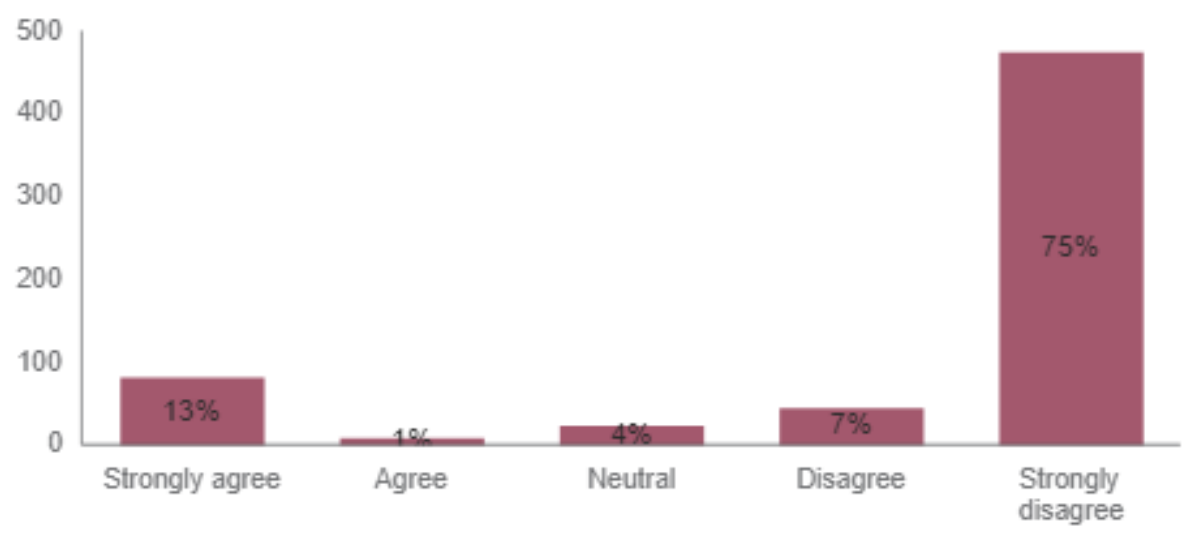

Figure 8. Respondent's answers about minimum wage as family support.

Source: Data obtained from the author's survey conducted for this paper named "Attitudes and beliefs about minimum wage and its effect in Kosovo's economy - results of a public survey."

For the questions in which respondents were asked about the effect of minimum wage on the standard of living in Kosovo, 95\% think that increasing the minimum wage will increase the standard of living in Kosovo.

Increasing the minimum wage will increase the standard of living in Kosovo

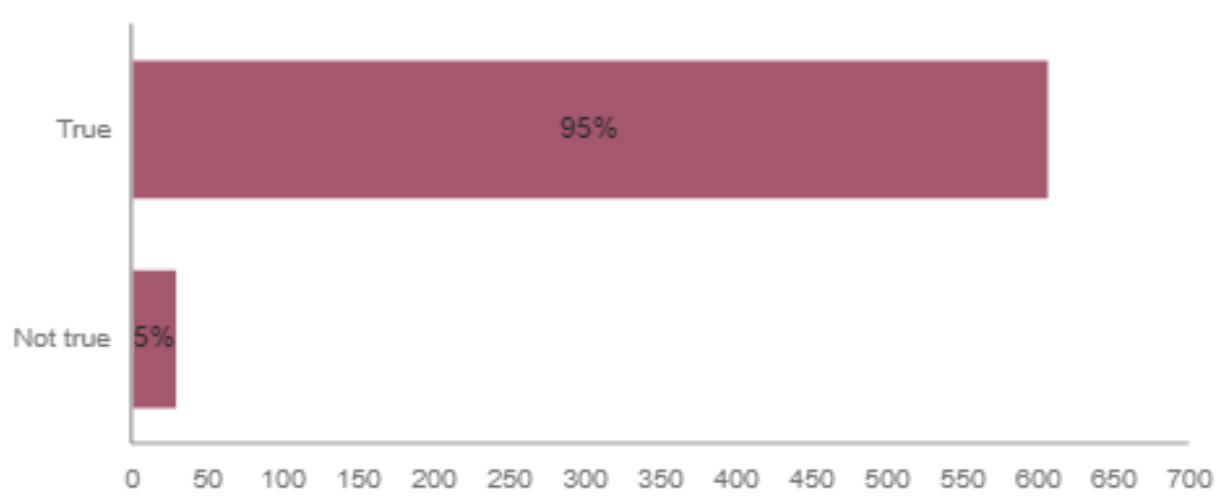

Figure 9. Respondent's answers about the effect of minimum wage on increasing the standard of living in Kosovo.

Source: Data obtained from the author's survey conducted for this paper named "Attitudes and beliefs about minimum wage and its effect in Kosovo's economy - results of a public survey."

Based on our findings, $93 \%$ of respondents think that increasing the minimum wage will do more good than harm to Kosovo's economy. Moreover, our survey findings show that $48 \%$ of respondents strongly disagree, and $11 \%$ of them agree that an increase in the minimum wage in Kosovo will cause layoffs. In addition, $24 \%$ of respondents are neutral (see Figures 10 and 11 ). 


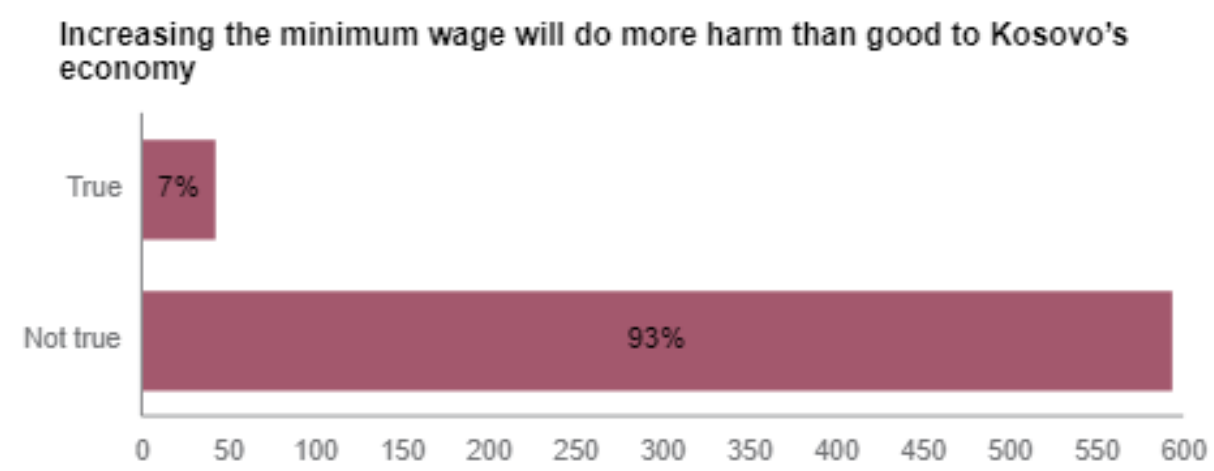

Figure 10. Respondent's answers about the effect of increasing minimum wage in Kosovo's economy.

Source: Data obtained from the author's survey conducted for this paper named "Attitudes and beliefs about minimum wage and its effect in Kosovo's economy - results of a public survey."

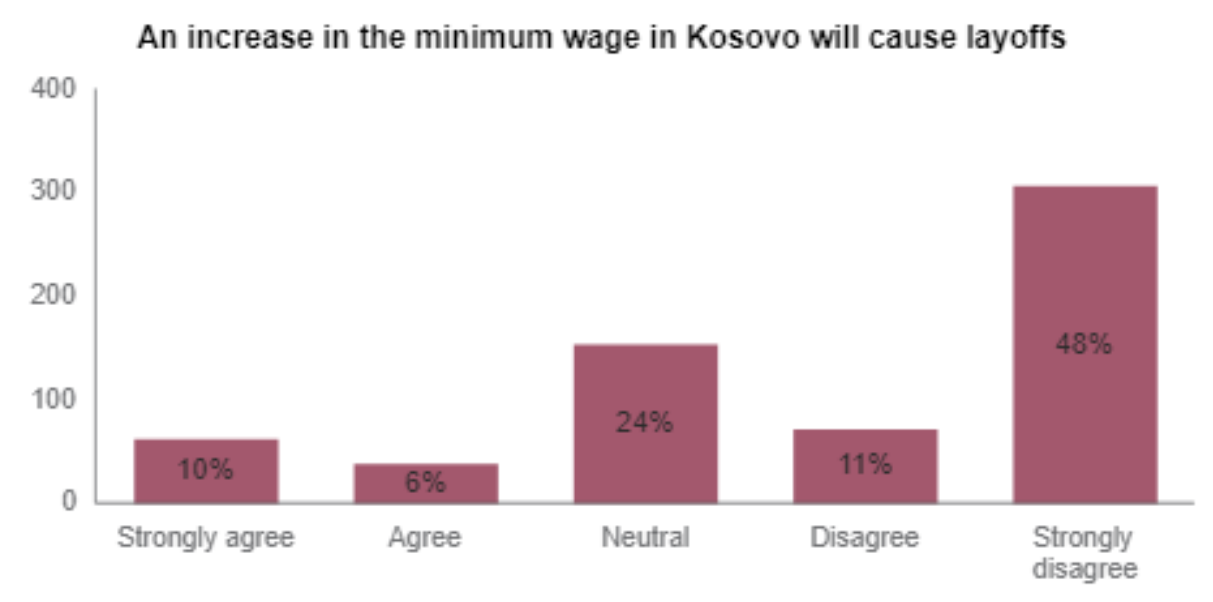

Figure 11. Respondent's answers about the effect of increasing the minimum wage on employment

Source: Data obtained from the author's survey conducted for this paper named "Attitudes and beliefs about minimum wage and its effect in Kosovo's economy - results of a public survey."

Our results show that $84 \%$ of respondents think that the private sector would be affected the most by increasing the minimum wage. On the other hand, $16 \%$ of respondents think that increasing the minimum wage would affect the public sector. Furthermore, our survey findings show that $59 \%$ of respondents think that an increase in the minimum wage would increase employment. On the other hand, $12 \%$ of respondents think that employment will decrease, and $29 \%$ have no opinion. Regarding the impact of the increase in the minimum wage in the public sector, $45 \%$ of respondents think that employment will increase, $15 \%$ think that employment will decrease, and $41 \%$ think that there will be no impact (see Figures 12 and 13). 
Which sector would be affected the most by increasing the minimum wage?

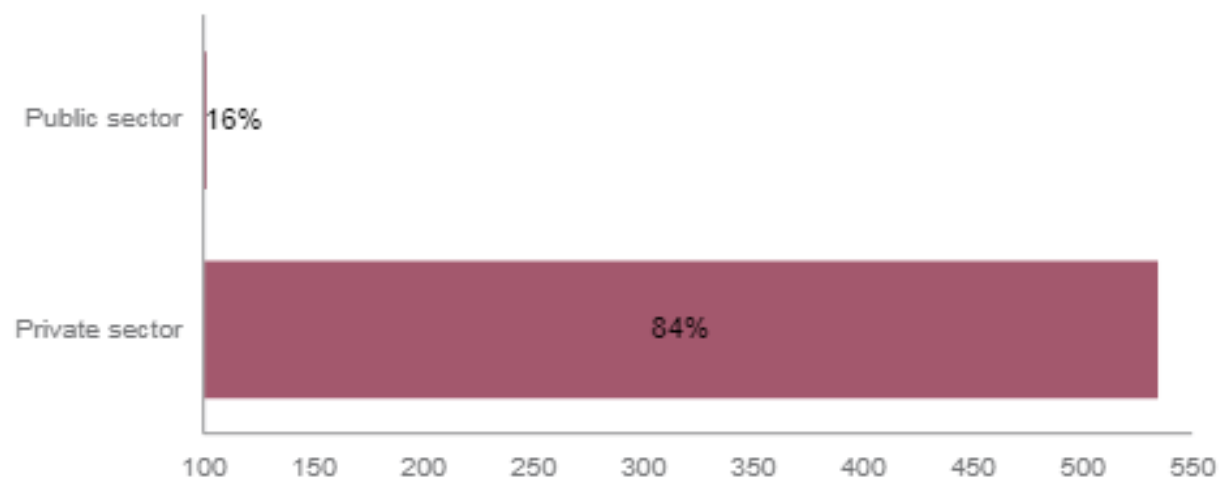

Figure 12. Respondent's answers about the effect of increasing minimum wage in the private and public sector.

Source: Data obtained from the author's survey conducted for this paper named "Attitudes and beliefs about minimum wage and its effect in Kosovo's economy - results of a public survey."

\section{In your opinion, how will an increase in the minimum In your opinion, what will be the impact of the increase wage in Kosovo affect the labor market in general? in the minimum wage in the public sector?}

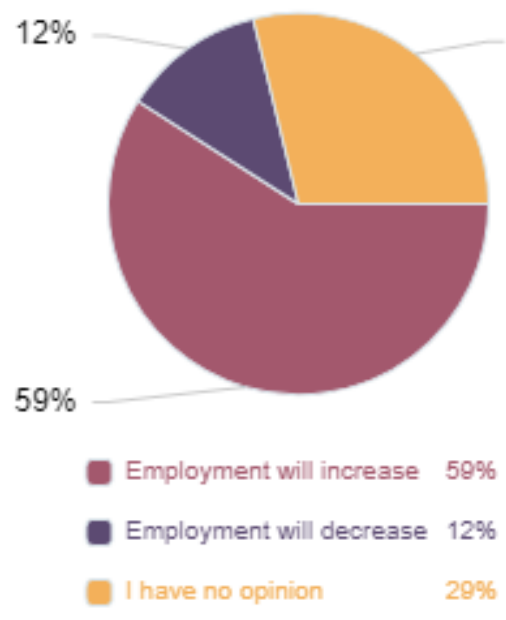

(a)

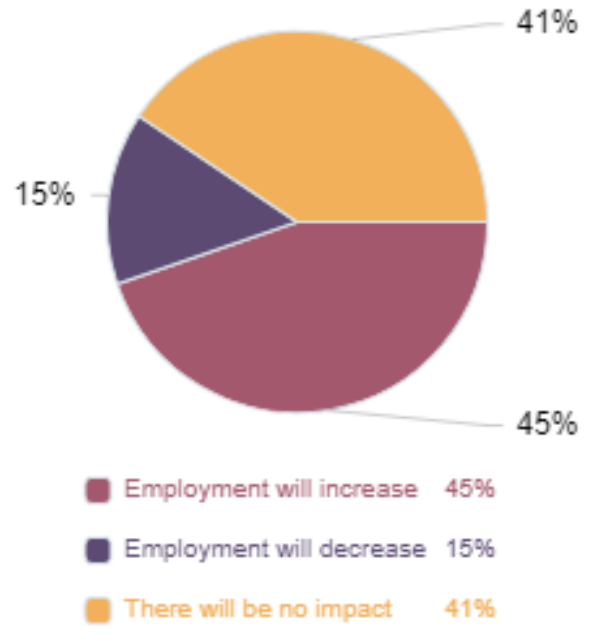

(b)

Figure 13. Respondent's answers about the impact of the increase in the minimum wage in the labour market in general and in the public sector.

Source: Data obtained from the author's survey conducted for this paper named "Attitudes and beliefs about minimum wage and its effect in Kosovo's economy - results of a public survey."

Our findings for the opinion of respondents for the impact of the increase of minimum wage in the informal sector show that $41 \%$ of respondents have a neutral opinion, $20 \%$ of them strongly disagree, and $18 \%$ strongly agree that increasing the minimum wage will increase employment in the informal sector. 


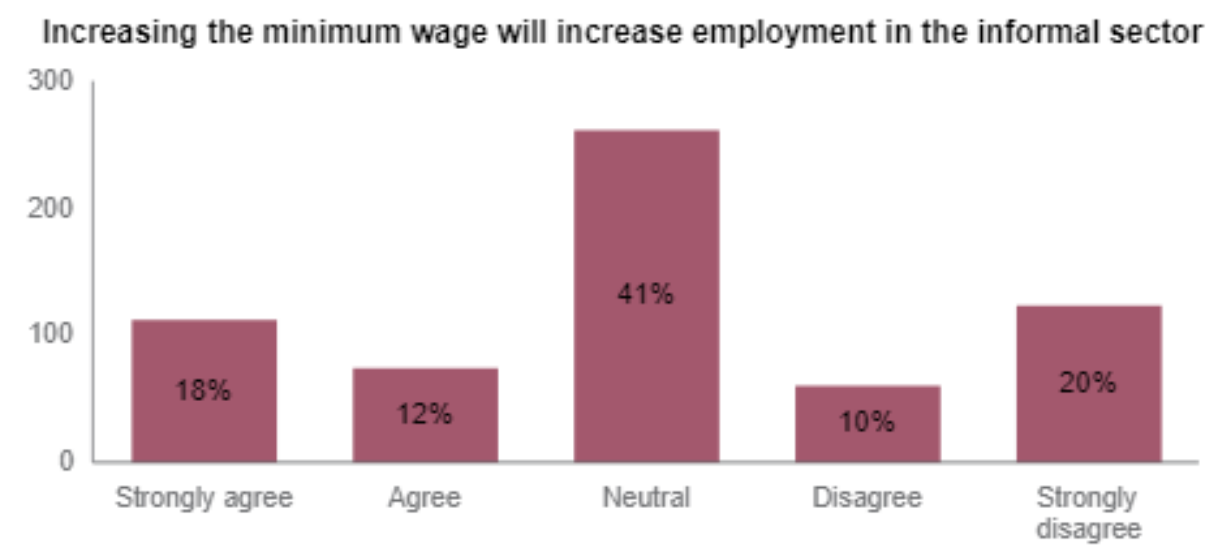

Figure 14. Respondent's answers about the impact of increasing the minimum wage in the informal sector.

Source: Data obtained from the author's survey conducted for this paper named "Attitudes and beliefs about minimum wage and its effect in Kosovo's economy - results of a public survey."

In the following questions, respondents were asked for their opinion on increasing the minimum wage to reduce poverty in the country. $43 \%$ of respondents strongly agree, and $17 \%$ agree that increasing the minimum wage will reduce poverty in the country.

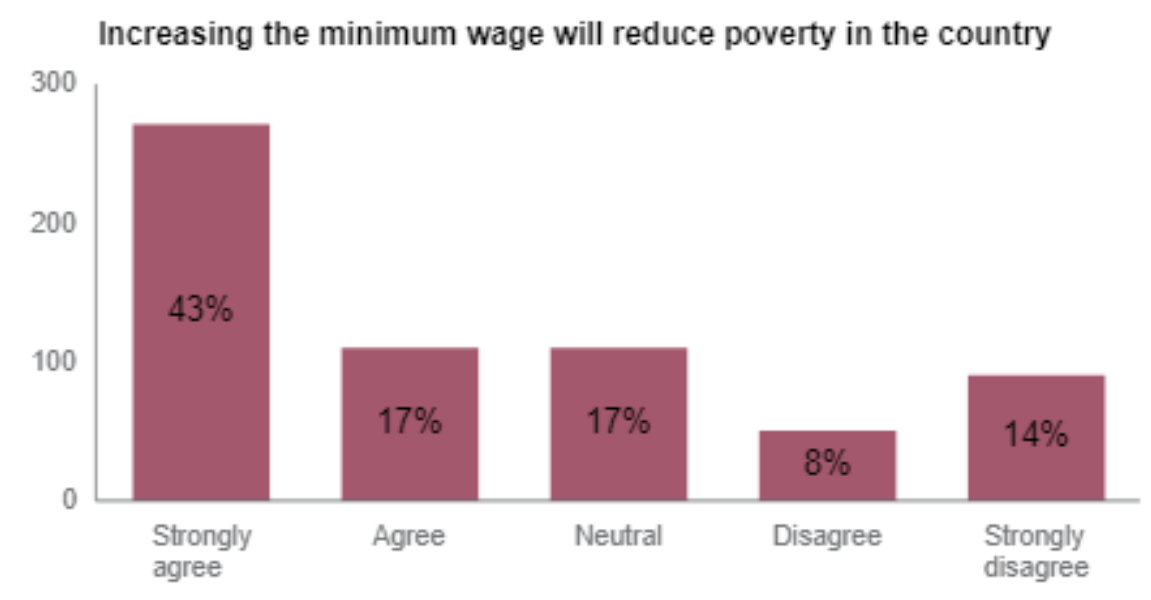

Figure 15. Respondent's answers about the impact of increasing the minimum wage in reducing poverty in the country.

Source: Data obtained from the author's survey conducted for this paper named "Attitudes and beliefs about minimum wage and its effect in Kosovo's economy - results of a public survey."

Based on the finding from our survey, $75 \%$ of respondents agree that the increase in the minimum wage will affect the increase in wages in general. 
The increase in the minimum wage will affect the increase in wages in general

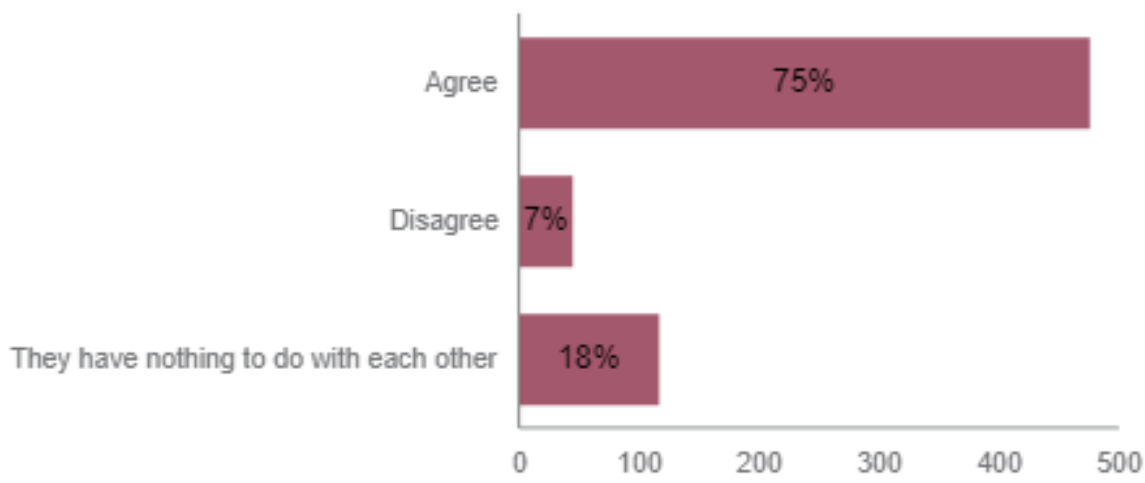

Figure 16. Respondent's answers about the impact of increasing the minimum wage in wages in general.

Source: Data obtained from the author's survey conducted for this paper named "Attitudes and beliefs about minimum wage and its effect in Kosovo's economy - results of a public survey."

The last questions asked respondents what would their opinion be if the government were to increase the minimum wage. $99 \%$ of respondents said they would agree on the matter. If the government of Kosovo were to suggest an increase in the minimum wage,
what would you think?

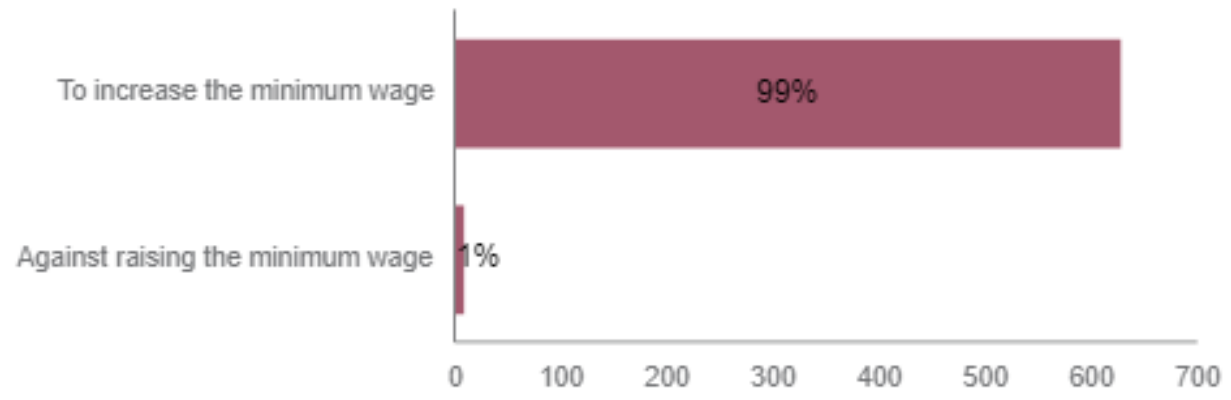

Figure 15. Respondent's answers about their opinion about increasing the minimum wage as a government suggestion.

Source: Data obtained from the author's survey conducted for this paper named "Attitudes and beliefs about minimum wage and its effect in Kosovo's economy - results of a public survey."

\section{Conclusions and Recommendations}

In this paper, we analyzed the effect of the minimum wage on Kosovo's economy based on the survey we conducted with 635 respondents. Ranging from general questions to more specific ones, we have tried to make our survey as representative as possible, including participants from different professions, to see their perceptions and attitudes regarding the minimum wage in Kosovo. According to the results, $70 \%$ of respondents think that the minimum wage has impacted their work or career, and $68 \%$ strongly agree that the minimum wage in Kosovo should be increased. In addition, $75 \%$ of respondents strongly disagree that the minimum wage is enough to support a family. Moreover, $95 \%$ of respondents think that increasing the minimum wage will increase the standard of living in Kosovo. Similarly, 93\% of them think that 
increasing the minimum wage will do more good than harm to Kosovo's economy, and $84 \%$ of respondents think that the private sector would be affected the most by increasing the minimum wage.

More than half of the respondents agree that the increase in the minimum wage will affect wages in general, and almost all of the respondents are willing to increase the minimum wage if the government of Kosovo suggests an increase in the minimum wage.

In general, based on our findings, we can conclude that our respondents have positive attitudes and beliefs about the minimum wage and its effect on Kosovo's economy. Because the minimum wage in Kosovo has not increased since 2011, the purpose of this paper is to provide an overview of the minimum wage in Kosovo by making an additional contribution to the existing literature and passing a message to policymakers. Based on our findings, we recommend that the government of Kosovo review the setting of the minimum wage in detail and propose its increase, always after analyzing its effects and consequences.

\section{References:}

Aaronson, D. and French, E. (2007). "Product Market Evidence on the Employment Effects of the Minimum Wage", Journal of Labour Economics, 25(1), 167-200. doi:10.1086/508734

Belman, D. and Wolfson, P. (2014). "What Does the Minimum Wage Do?" Kalamazoo, Michigan: W.E. Upjohn Institute. pp. 21-118. http://www.jstor.org/stable/j.ctvh4zgf2.6

Brecher, R. A. (1974). "Minimum Wage Rates and the Pure Theory of International Trade". The Quarterly Journal of Economics, 88(1), pp. 98-116. doi:10.2307/1881796

Brown, C. (1988). “Minimum Wage Laws: Are They Overrated?” Journal of Economic Perspectives, 2(3), 133-145. doi:10.1257/jep.2.3.133

Brown, C. Gilroy, C. and Kohen, A. (1982). "The Effect of the Minimum Wage on Employment and Unemployment: A survey", Working Paper No. 846. National Bureau of Economic Research. Cambridge MA.

Cahuc, P., and Michel, P. (1996). "Minimum wage unemployment and growth", European Economic Review, Vol. 40 No.2, 1463-1482, doi:10.1016/0014-2921(95)00035-6

Card, D. and Krueger, B.A. (1995). "Time-Series Minimum-Wage Studies: A Meta-analysis", The American Economic Review, Vol. 85 No. 2, pp. 238-243. American Economic Association.

Card, D. and Krueger, A. (1993). "Minimum Wages and Employment: A Case Study of the Fast Food Industry in New Jersey and Pennsylvania", Working Paper No 4509, National Bureau of Economic Research, Cambridge, doi:10.3386/w4509

Cengiz, D. Dube, A. Lindner, A. and Zipperer, B. (2019). "The Effect of Minimum Wages on Low-Wage Jobs", The Quarterly Journal of Economics, doi:10.1093/qje/qjz014

Clemens, J. and Wither, M. (2019). "The minimum wage and the Great Recession: Evidence of effects on the employment and income trajectories of low-skilled workers", Journal of Public Economics, Vol 170 No 2019, pp. 53-67. 
Del Carpio, X. V. and Pabon, L. M. (2017). "Implications of Minimum Wage Increases on Labour Market Dynamics: Lessons for Emerging Economies", Policy Research Working Paper; No. 8030. World Bank, Washington, DC.

Dinkelman, T. and Ranchhod, V. (2012). "Evidence on the impact of minimum wage laws in an informal sector: Domestic workers in South Africa" Journal of Development Economics, Vol 99 No 1, pp. 2745. doi:10.1016/j.jdeveco.2011.12.006

Dolado, J. K., Machin, F., Manning, A., Margolis, D. Teulings, C. (1996). "The Economic Impact of Minimum Wages in Europe. Economic Policy" Vol 11 No 23, pp. 317-372, doi:10.2307/1344707

Eurostat database. (2020).

https://ec.europa.eu/eurostat/databrowser/view/earn mw cur/default/table?lang=en

Eyraud, F. and Saget, C. (2005), "The fundamentals of minimum wage fixing", International Labour Office, Geneva.

Fajnzylber, P. R. (2001). "Minimum Wage Effects Throughout the Wage Distribution: Evidence from Brazil's Formal and Informal Sectors", CEDEPLAR Working Paper No. 151. http://dx.doi.org/10.2139/ssrn.269622

Freeman, R. B. (1996). "The Minimum Wage as a Redistributive Tool”, The Economic Journal, 106(436), 639. doi:10.2307/2235571

Gindling, T. H., and Terrell, K. (2005). "The effect of minimum wages on actual wages in formal and informal sectors in Costa Rica", World Development, Vol 33 No 11, pp. 19051921. doi:10.1016/j.worlddev.2005.04.017

Gramlich, E. (1976). "Impact of Minimum Wages on Other Wages, Employment, and Family Incomes", Brookings Papers on Economic Activity, Economic Studies Program, The Brookings Institution, Vol 7 No 2, pp. 409-462.

Grossman, J. B. (1983). "The Impact of the Minimum Wage on Other Wages", The Journal of Human Resources, Vol 18 No 3, pp. 359-378. doi:10.2307/145206

Harasztosi, P. and Lindner, A. (2019). "Who Pays for the Minimum Wage?" American Economic Review, 109 (8): 2693-2727.

Harrison, A. and Leamer, E. (1997). "Labour Markets in Developing Countries: An Agenda for Research. Journal of Labour Economics", Vol 15 No 3, pp 1-9. doi:10.1086/209852

Herr, H. and Kazandziska, M. (2011). Principles of Minimum Wage Policy - Economics, Institutions and Recommendations, Global Labour University Working Paper, No. 11, ISBN 9789221246473, International Labour Organization (ILO), Geneva

Horrigan, M. W. and Mincy, R. B. (1993). "The Minimum Wage and Earnings and Income Inequality", In Danziger, Sheldon, Gottschalk, Peter, eds., Uneven Tides: Rising Inequality in America. New York: Russell Sage Foundation, pp. 251-75.

Infante, R., Marinakis, A. and Velasco, J. (2003). Minimum wage in Chile: An example of the potential and limitations of this policy instrument, Employment Paper 2003/52, International Labour Office Geneva 
Katz, L. F., and Krueger, A. B. (1992). "The Effect of the Minimum Wage on the Fast-Food Industry", ILR Review, Vol 46 No 1, pp. 6-21. doi:10.1177/001979399204600102

Kosovo Agency of Statistics. (2020a). "Labour Force Survey in Kosovo, 2019”, Prishtina.

Kosovo Agency of Statistics. (2020b). "Wage Level in Kosovo, 2019”, Prishtina

Lee, D. S. (1999). "Wage Inequality in the United States During the 1980s: Rising Dispersion or Falling Minimum Wage?", The Quarterly Journal of Economics, Vol 114 No 3, pp. 9771023. doi:10.1162/003355399556197

Marinakis, A. (2009). "The role of ILO in the development of minimum wages" ILO, Santiago.

Meer, J., and West, J. (2015). Effects of the Minimum Wage on Employment Dynamics. Journal of Human Resources, 51(2), 500-522. doi:10.3368/jhr.51.2.0414-6298r1

Neumark, D. and Wascher, W. (1992). "Employment Effects of Minimum and Subminimum Wages: Panel Data on State Minimum Wage Laws", ILR Review, Vol 46 No 1, 5581. doi:10.1177/001979399204600105

Neumark, D. and Wascher, W. (1994). "Employment Effects of Minimum and Subminimum Wages: Reply to Card, Katz, and Krueger" ILR Review, Vol 47 No 3, pp. 497512. doi:10.1177/001979399404700309

Neumark, D. and Wascher, W. (1995). "Minimum-Wage Effects on School and Work Transitions of Teenagers", The American Economic Review, Vol 85 No 2, pp 244-249. Papers and Proceedings of the Hundredth and Seventh Annual Meeting of the American Economic Review, Washington DC.

Neumark, D. and Wascher, W. (2008). "Minimum Wages", Massachusetts Institute of Technology. Cambridge, London.

OECD. (2015). "Minimum wages after the crisis: Making them pay". http://www.oecd.org/social/Focus-on-Minimum-Wages-after-the-crisis-2015.pdf

Official Newspaper of the Republic of Kosovo. (2010). Law No. 03/L-212. https://gzk.rksgov.net/ActDetail.aspx?ActID=2735

Rutkowski, J. (2003). "The minimum wage: curse or cure?", Human Development Economics Europe and Central Asia Region, The World Bank. https://openknowledge.worldbank.org/handle/10986/26468

Stigler, J.G. (1946). "The Economics of Minimum Wage Legislation", The American Economic Review, Vol 36 No 3, pp. 358-365. American Economic Association.

Suryahadi, A. Widyanti, W. Perwira, D. and Sumarto, S. (2003). "Minimum wage policy and its impact on employment in the urban formal sector", Bulletin of Indonesian Economic Studies, Vol 39 No 1, pp. 29-50. doi:10.1080/00074910302007

Webb, S. (1912). "The economic theory of a legal minimum wage", The Journal of Political Economy, Vol 20 No 10, pp. 973-998.

Welch, F. (1974). "Minimum Wage Legislation in the United States", Economic Inquiry, Vol 12 No 3, pp. 285-318. doi:10.1111/j.1465-7295.1974.tb00401.x

Zavodny, M. (2000). "The effect of the minimum wage on employment and hours", Labour Economics, Vol 7 No 6, pp.729-750. doi:10.1016/s0927-5371(00)00021-x

PAGE 165| Journal of Corporate Governance, Insurance, and Risk Management | 2021, VOL. 8, Series. 1 